This PDF is a selection from a published volume from the National Bureau of Economic Research

Volume Title: International Trade in East Asia, NBER-East Asia Seminar on Economics, Volume 14

Volume Author/Editor: Takatoshi Ito and Andrew K. Rose, editors

Volume Publisher: University of Chicago Press

Volume ISBN: 0-226-37896-9

Volume URL: http://www.nber.org/books/ito_05-1

Conference Date: September 5-7, 2003

Publication Date: August 2005

Title: The Growing Problem of Antidumping Protection

Author: Thomas J. Prusa

URL: http://www.nber.org/chapters/c0198 


\title{
The Growing Problem of Antidumping Protection
}

\author{
Thomas J. Prusa
}

\subsection{Introduction}

While the public's and press's imagination has tended to focus on hotbutton issues such as agriculture, labor standards, and the environment, it is the dozens, if not hundreds, of other less publicly visible policies that will largely determine the success of the Doha Round of the World Trade Organization (WTO). Chief among these less celebrated policies is antidumping (AD).

Antidumping is a fairly inconspicuous trade policy - I have never seen a picture of a WTO protestor carrying a placard lamenting the spread of $\mathrm{AD}$ or, for that matter, praising the virtues of $\mathrm{AD}$. Despite its somewhat low public profile, many studies have shown that $\mathrm{AD}$ imposes heavy costs on both implementing and affected countries. For instance, Gallaway, Blonigen, and Flynn (1999) estimate that only the Multifiber Arrangement imposes larger welfare costs on the U.S. economy than do antidumping and countervailing duty actions. ${ }^{1}$ Messerlin (2001) estimates that AD protection and farm policies were about equally as costly for European Union

Thomas J. Prusa is professor of economics at Rutgers University and a research associate of the National Bureau of Economic Research.

Much of the analysis included in this paper was done while I was a visitor at the East-West Center. The Center's hospitality and research support is deeply appreciated. I would also like to thank WTO Rules Division, and Jorge Miranda in particular, for making the WTO AD Measures Database available. As always, all mistakes and errors are my responsibility.

1. Data limitations require Gallaway, Blonigen, and Flynn (1999) to combine antidumping and countervailing duty protection in their analysis. Given that there were more than twice as many antidumping cases as countervailing duty cases, there is little sense that the primary distortion is due to countervailing duties. Perhaps more important, it should be recognized that their analysis year (1991) was one in which relatively few AD measures were in force in the United States. For instance, in 1991 most steel products from most countries were covered by an orderly marketing arrangement (OMA) and were not part of the Gallaway, Blonigen, and 
(EU) countries. In terms of trade volume, Staiger and Wolak (1994) and Prusa (2001) each find that trade from affected countries often falls by more than 50 percent after the imposition of AD duties.

If $\mathrm{AD}$ protection is so costly, why has it remained a back-burner topic? There are two interrelated explanations. The first is quite simple: until ten to fifteen years ago, the AD users club was fairly small, making it easy for countries seeking reform to believe that $\mathrm{AD}$ was essentially a nuisance and hence to give it lower priority in negotiations. The second reason is that the four traditional users of AD-Canada, the United States, the EU, and Australia - have believed and continue to believe that more would be lost than gained if $\mathrm{AD}$ were to be reformed (from a mercantilist point of view).

But these explanations are no longer supported by the facts. While AD supporters may not be surprised to hear that $\mathrm{AD}$ is poised to become the world's biggest trade impediment, they may be shocked when they hear its ascendancy is primarily due to the AD activity of new users. Twenty years ago the top four users accounted for 98 percent of AD actions; nowadays these traditional AD users account for only about 40 percent of the disputes. Said differently, even though AD activity among the traditional users has fallen by about 25 percent over the past decade, total worldwide $\mathrm{AD}$ activity is up over 15 percent. Over the past decade the number of countries with an AD statute has doubled, and over the past twenty years the number of countries actively using AD has quadrupled. Put another way, within a few years the list of countries not using AD will be shorter than the list of countries of using AD. The once exclusive AD club now includes members from all parts of the globe and from all income levels.

Although the United States, Australia, and the EU still file more cases than other countries do, it now seems inevitable they will be passed by countries such as India, Mexico, Brazil, and perhaps most remarkable of all, the People's Republic of China. Once I control for size, it becomes apparent that new users are filing at prodigious rates, five, ten, and even twenty times the rate as the traditional users. These filing trends imply that the traditional users' mercantilist rationale for $\mathrm{AD}$ is rapidly eroding.

While some of these issues have been discussed in the literature (Miranda, Torres, and Ruiz 1998; Prusa 2001; Zanardi 2004), there has been no discussion of what these evolving trends mean for Asia-Pacific countries, the traditional target of AD protection. Supporters of AD often make reference to "sanctuary markets," "foreign cartels," and "establishing level playing fields" in their rhetoric; their comments implicitly or explicitly allude to Japan, South Korea, and the People's Republic of China. ${ }^{2}$

During the 1980s the Asia-Pacific countries were the targets of 30-40 percent of traditional users' AD actions. Has the spread of AD protection

Flynn (1999) calculation. Given that the steel industry accounts for about 30 percent of all U.S. actions, their estimate is probably a lower bound of the impact of U.S. antidumping protection.

2. The standard arguments justifying the need for AD protection can be found in Mastel (1998) and Cohen, Blecker, and Whitney (2003). 
changed this? Or do Asia-Pacific countries continue to bear a disproportionate share of $\mathrm{AD}$ protection? I find that the proliferation has done nothing to alter the pattern: over the past decade Asia-Pacific countries are subject to about 40 percent of both new and traditional user $\mathrm{AD}$ actions.

Interestingly, I do see differences in the industry composition of trade complaints between new and traditional users. Traditional and new users both tend to target industries where they are losing comparative advantage. Because this pattern varies across countries, however, AD complaints differ across source countries. In other words, the pattern of AD use says as much about the filing country as it does about the target countries. If country A's steel industry is ailing, then country A targets South Korea's steel companies. If country B's apparel sector is ailing, then country B targets South Korea's apparel companies. If country C's tire industry is ailing, then country C targets South Korea's tire companies.

Interestingly, when one controls for general macroeconomic influences on the quantity of AD disputes among nations, I find broadly similar patterns for new users (in general), Asian countries (specifically), and the traditional users. Exchange rate appreciations, weak gross domestic product (GDP) growth, and strong import growth all stimulate AD activity. I find some support for the view that the exchange rate matters less for new users, which suggests that new users have an even weaker injury test than traditional users do.

These evolving trends mean that Asia-Pacific nations' position toward $\mathrm{AD}$ reform is more complicated than in the past. On the one hand, they have been, and continue to be, subject to huge numbers of AD measures. Reforming AD rules is in their national interest. On the other hand, evidence is emerging that Asia-Pacific nations are learning the joys of discretionary protection. Reforming AD rules will present commercial challenges to many powerful industries. For many new users the political calculus toward AD reform will soon shift (or in some cases, has already shifted) toward maintaining current rules.

The rest of the paper proceeds as follows. In the next section I give a quick primer on AD rules and protection; the discussion highlights the disconnect between the theoretical justification for and the actual practice of $\mathrm{AD}$ protection. I then review the trends in $\mathrm{AD}$ measures and document the growing set of countries using AD. In section 10.4 I focus on AD protection by and against Asia-Pacific countries. In section 10.5 I examine how macroeconomic variables affect new and traditional user filing activity. Section 10.6 concludes with a discussion of how Asia-Pacific countries might pursue $\mathrm{AD}$ reform.

\subsection{Antidumping Overview - The Yawning Gap Between Theory and Practice}

Under General Agreement on Tariffs and Trade (GATT)/WTO rules, antidumping law protects domestic industries from unfair import compe- 
tition. Specifically, AD law allows a country to impose special duties on goods from a particular country or group of countries if two claims can be proven: (a) that the imported goods are being sold in the domestic market at "dumped" prices; and (b) that the imports in question are causing or threatening to cause "material injury" to domestic producers of the "like product."

Antidumping supporters argue that dumping violates principles of fair trade and as such must be condemned. To the man on the street this broad description makes AD sound fine and, if anything, sounds vaguely reminiscent of antitrust law. If nothing else, the rhetoric of "free but fair" trade is irresistible. After all, who is in favor of unfair trade?

\subsubsection{The Question of Dumping}

To most people, AD law sounds like it is rooted in solid economicsnamely, the idea that policymakers should discourage anticompetitive practices. There has been more than a century of legal analysis of what constitutes anticompetitive behavior through application of antitrust laws. Unfortunately, the definition of "unfair" trade practices and the application of AD remedies has been allowed to develop a life of its own and bears no resemblance to established standards of anticompetitive behavior. The anticompetitive practice most relevant to our AD discussion here is predatory pricing. This is where a firm prices low with the intent of driving rivals out of business. The standard for judging whether a firm is pricing in such a manner is to examine whether a firm's price falls below its marginal cost. Because marginal cost is essentially unobservable, Areeda and Turner (1975) have alternatively suggested looking at whether price is below average variable cost, that is, excluding fixed costs.

In simplest terms, dumping is simply defined as the practice of a firm selling at a price in its export market that is below "fair" value. Application of this definition is not so simple as it involves a more precise definition of "fair." In practice, two main ways have evolved to calculate fair value: (a) The price charged by the exporting firm in its own market for the same product, or (b) the cost of the product constructed from firm-level accounting data. ${ }^{3}$

Both of these definitions are very weak in terms of identifying economic behavior that could be considered anticompetitive, that is, the criteria to judge whether predatory pricing is occurring. Under the first definition, a firm is dumping simply by price discriminating, that is, charging different

3. The cost-based definition of dumping was only codified into GATT AD rules during the Tokyo Round. This amendment was demanded by domestic industries (most notably steel) in order to make AD more protective. As Messerlin (1989), Clarida (1996), and Lindsey (1999) have reported, U.S. and EU AD disputes are now being dominated by cost-based allegations. Such trends have led one noted legal expert to claim that cost-based AD petitions have become "the dominant feature of US antidumping law" (Horlick 1989, 136). 
prices in different markets. It is virtually impossible to find a market in which firms are not price discriminating in some way, and antitrust laws do not deem this practice as anticompetitive per se. ${ }^{4}$ If countries do not worry about price discrimination by firms for different consumers in the domestic economy, why should we worry about it across national borders?

The second definition of "fair" value leads to an even more ridiculous criterion by antitrust standards. As mentioned, antitrust authorities do worry about pricing below marginal cost (or, in practice, average variable cost), as this has become the standard for believing that the firm is not maximizing short-run profits but instead pricing in a predatory fashion to drive out rivals. In fact, one can see that relaxing standards to prosecute any firm that prices below average total cost (including fixed costs) for antitrust violations is ridiculous. This would mean that one could prosecute any firm that is making a loss. Yet, when many countries' antidumping authorities determine "fair value" through "constructed cost" measures, they not only include fixed costs, but they also add on their own estimate for what should be a normal profit for the firm in the market. As a result, they take the ridiculous to another level and convict a foreign firm for not making enough economic profit from a country's consumers.

Given this discussion, it should come as little surprise that almost all dumping determinations are affirmative and that dumping margins are usually quite large. In the United States, for example, over the past twentyfive years about 98 percent of the dumping determinations have been affirmative, and over the past five years the average calculated margin has exceeded 50 percent. While I do not have complete data on dumping determinations for other countries (an ongoing project), my preliminary research indicates that similar extreme patterns hold for other countries.

While one could argue that AD cases are only brought against firms who have violated some reasonable business principles, the simple truth is that if one were to apply $\mathrm{AD}$ regulations to domestic markets, one would discover not only that any firm that loses money has dumped (by definition) but also that any firm that does not report double-digit profits has dumped. In fact, WTO rules allow a country to claim an import is being dumped even though the foreign firm charges not only higher prices abroad than it does at home but also higher prices than its domestic competitors. Lindsey and Ikenson (2002) show how a producer that sells widgets in the export market at prices 13.96 percent higher than in its home market nonetheless winds up with a dumping margin of 7.37 percent.

4. In other words, its mere existence is not enough to rule the behavior illegal. It must be shown that the practice is intended to harm competition. Viscusi, Kip, and Harrington (1995) conclude that the enforcement of the U.S. Robinson-Patman Act against price discrimination for cases where it was a potentially anticompetitive behavior actually led to anticompetitive results and conclude, "Fortunately, enforcement by the Federal Trade Commission has declined in recent years" (298). 
Indeed, WTO-sanctioned methodology implies that not only have most domestic firms "dumped" during bad years (when they announce losses) but also that most firms (foreign or domestic) dump even in good years simply because they report single-digit profit margins. Bluntly stated, according to how the GATT/WTO has defined the term, most economic transactions involve "dumping."

\subsubsection{The Question of Causality}

Under WTO rules, affirmative AD determinations with resulting AD duties require a finding of not only dumping but also of material injury (or threat of injury) to the domestic firm due to import competition. Of course, saying that having a foreign competitor in the market place is injurious to a domestic firm is like saying that water is wet. Competition reduces current firms' profitability, which is an indication of efficient markets. The criterion of "material" injury only raises the bar slightly by ruling out trivially small competitors. For all intents and purposes, in AD injury analysis, correlation and causality are the same. Remember, the legal standard is "material injury," and material injury can be interpreted as loosely as local authorities choose. As a practical matter, if there has been any increase in imports over the same time period that virtually any measure of economic performance has declined, imports can be blamed. Whether similar correlations exists between dozens of other potential factors is usually beside the point. Moreover, such marketplace occurrences have no necessary correlation with anticompetitive practices.

\subsubsection{What AD Is Not (Competition Policy) and What AD Is (Protectionism)}

As the preceding discussion suggests, $\mathrm{AD}$ is not antitrust law. The term "unfair" has evolved to mean something completely different in the practice of AD protection than standard notions of "anticompetitive." As such, there is a very large disconnect between AD protection and the competition policy of developed countries. Any changes in the marketplace that lead to less favorable outcomes for the domestic firm are considered unfair so that AD laws are truly about protecting domestic firms' interests, not competition. This places us back into the familiar realm of "beggar-thyneighbor" trade policies, with many of the well-known economic welfare consequences. ${ }^{5}$

If $\mathrm{AD}$ is not about making markets competitive, what is it? For all intents and purposes, $\mathrm{AD}$ is simply protectionism dressed up in a nice suit. In many ways, AD is an almost ideal instrument of modern protection. First, it is sanctioned by the WTO. As a consequence, targeted countries cannot

5. The problems with AD are worse than this discussion suggests. As discussed at length in Blonigen and Prusa (2003), one of the ironies is that the economic literature has shown that $\mathrm{AD}$ laws likely help facilitate anticompetitive behavior on the part of firms. 
immediately retaliate to a dumping order by raising their own tariffs. Implementing countries can always claim they are just exercising their negotiated right to "level the playing field." AD law allows politicians to offer protection to politically preferred industries without blatantly violating their GATT/WTO obligations. Second, the legal standards are, at best, easily satisfied and murky and, at the worst, nonsensical. As a result, AD duties always have a significant probability of satisfying the legal rules. As a result, AD duties often are nothing more than veiled protectionism. Third, as shown by Staiger and Wolak (1994), even a case that is ultimately rejected can significantly reduce trade. During the course of the investigation (usually about a year) the foreign companies are guilty until proven innocent. As a result, duties are imposed long before the final determination is made. This means that in many cases the attempt to restrain foreign rival's with higher tariffs is effectively costless: the legal fees associated with the filing are more than paid for by the increased profits stemming from the investigation effect. Fourth, subject countries can appeal the AD determination to the WTO dispute settlement body, but this is rare and the appeal process is lengthy. ${ }^{6}$ Moreover, during the entire review process the $\mathrm{AD} \mathrm{du}-$ ties remain in force. And then, even if its appeal is ultimately successful, the affected party has to wait for the implementing country to alter its policy. The bottom line: even if the appeal eventually results in it the removal of the $\mathrm{AD}$ order, the $\mathrm{AD}$ action can have affected trade for five or more years.

All things considered, most people only understand the rhetoric surrounding $\mathrm{AD}$ and know little how $\mathrm{AD}$ is actually implemented. Of those in the know, all but AD's staunchest supporters recognize that AD has nothing to do with keeping trade fair. AD has nothing to do with moral right or wrong; it is simply another tool to improve the competitive position of the complainant against other companies. As Stiglitz (1997) argues, there is essentially no connection between national welfare considerations and AD protection.

\subsection{Emerging Trends in Antidumping Use- The Emergence of New Users}

In order to get a handle on how widespread AD is, I reviewed the semiannual reports submitted to the WTO by member countries. ${ }^{7}$ By agreement, all WTO members are required to make a semiannual report on their use of trade remedies, including antidumping activity. ${ }^{8}$ Using these reports

6. Durling (2003) documents that only a tiny fraction of AD measures even request WTO consultations. He also finds that the typical WTO AD appeal takes more than three years to final determination.

7. Reports are available at http://www.wto.org.

8. Zanardi (2004) also reports AD activity by non-WTO members such as Taiwan and Russia and the People's Republic of China prior to their membership. My statistics do not include these additional disputes. Overall the differences between Zanardi's aggregate statistics and mine are minor. 
I compiled a database of all AD actions filed by WTO members between 1980 and June 2002. In this section I will review the long-run trends in AD use and discuss the rising use of AD by new users. In the next section I will focus specifically on use of AD by East Asia and South Asia countries.

\subsubsection{AD - The 900 Pound Gorilla}

To say that antidumping is now the most popular form of international trade protection is an understatement. In terms of the quantity of trade litigation, antidumping has lapped the field - several times over. Between 1995 and 2000, WTO members reported 61 safeguard investigations, 115 countervailing duty investigations, and 1,441 antidumping investigations. When one recognizes that countervailing duty has long been the second most commonly used trade statute the filing statistics are even more astounding. Countervailing duty law takes the silver medal, but it is a distant second.

The preeminence of antidumping is neither an entirely recent phenomenon nor simply a one-year anomaly. In the United States, for instance, over the past twenty-five years there have been more than twice as many antidumping disputes as countervailing duty allegations. In fact, there have been more disputes filed under the U.S. antidumping statute than under all other U.S. trade statutes put together. The same is true for the EU. Antidumping is simply the 900-pound gorilla of trade laws.

\subsubsection{A Long-Run Perspective on AD}

There has been a steady, long-run increase in AD activity. In figure 10.1 I depict the number of filings since 1980. In order to give a broader picture and also to smooth year-to-year fluctuations, I have aggregated the annual statistics into five-year intervals. I have also extrapolated the data for January 2000 through June 2002 to come up with an estimated figure for the 2000-2004 period. As shown, starting from a base of about 700 AD disputes in 1980-1984, AD activity grew to over 1,200 disputes in 1990-1994 to over 1,400 disputes in 2000-2004 (estimated). Said differently, the number of AD disputes has doubled since the end of the Tokyo Round, which implies AD has averaged an annual growth rate of about 3.5 percent.

Of course, one reason why we have witnessed such a growth in AD disputes is the growth in trade. That is, as trade increases it should not be surprising to see an increase in dumping allegations. It therefore makes sense to control for the value of imports. Filing intensity not only gives an alternative measure of the long-run growth in $\mathrm{AD}$ but also facilitates comparing $\mathrm{AD}$ activity across countries. That is, the United States and EU are the world's largest importers and, as a result, they might be expected to file more cases. A country like New Zealand, for instance, may file fewer cases, but relative to what it imports, those few cases might indicate a very active AD policy. 


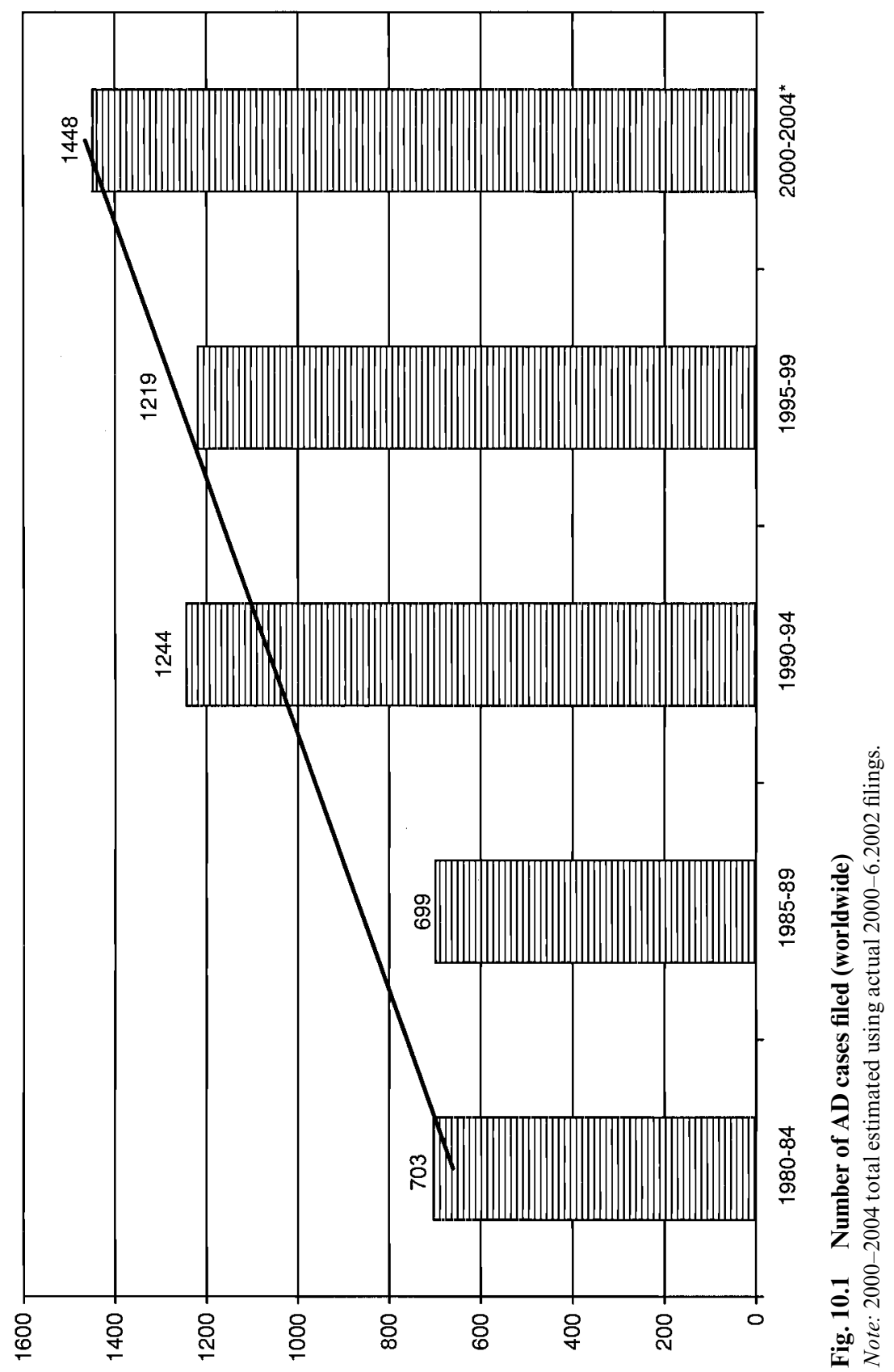


I compute an "intensity" of AD metric by calculating the number of cases per real dollar of imports and normalize the intensity measure so that the intensity level (for the entire 1980-2002 period) of the world's heaviest AD user, the United States, is set to one. ${ }^{9}$ Countries with intensity measures greater (less) than one file more (fewer) AD cases per dollar of imports than the United States.

In figure 10.2 depicts the intensity of AD filings since 1980. A couple of interesting lessons emerge. First, one's perspective on the long-run pattern of AD usage changes depending on whether I look at the raw numbers or intensity rate. Specifically, in figure 10.1 we saw that there has been a steady, long-run increase in AD activity; however, as shown in figure 10.2 the intensity of $\mathrm{AD}$ activity has experienced a steady, long-run decrease. Overall, the intensity of AD activity has steadily fallen about 2.4 to 1.5 over the past twenty years. In other words, even though the number of AD disputes has steadily increased, the volume of international trade has grown by an even faster rate. Figure 10.2 suggests that an important reason for the growth in $\mathrm{AD}$ is the growth in international trade. As it turns out, this is indeed a key lesson, but as I will discuss in the following, the lesson is somewhat subtler.

Second, as depicted in figure 10.2, on average, most other countries that file AD actions do so at about twice as intensively as the United States. In other words, even though the U.S. files more AD cases than any other country, when measured using the intensity index, the United States emerges as a fairly restrained user. The same is true for the EU (see table 10.1). In particular, the EU files a large number of cases, but its AD filing intensity puts it near the bottom of the list. By contrast, Australia and Canada, the other two traditional AD users, not only file a large number of cases but also have filing intensities that easily exceed that of the United States and EU. From the mercantilist perspective, these trends are a first indication that the EU and the United States have reason to be concerned by other countries' use of AD.

\subsubsection{The Growth of New Users}

Figure 10.2 does not incorporate the changing set of countries using AD protection over the sample period. Depending on the number and import intensity of new AD users, the preceding statistics might give a misleading impression of the trend in AD protection.

In table 10.2 I provide some information to help identify this trend. First, note the increase in the number of countries with AD statutes. Notice that early in the sample, only thirty-four nations/regions had an AD statute in their regulations governing international trade. Over time, more and more countries have codified their own AD statute. By 1990-1994, the number

9. Finger, $\mathrm{Ng}$, and Wangchuk (2001) perform a similar calculation. 


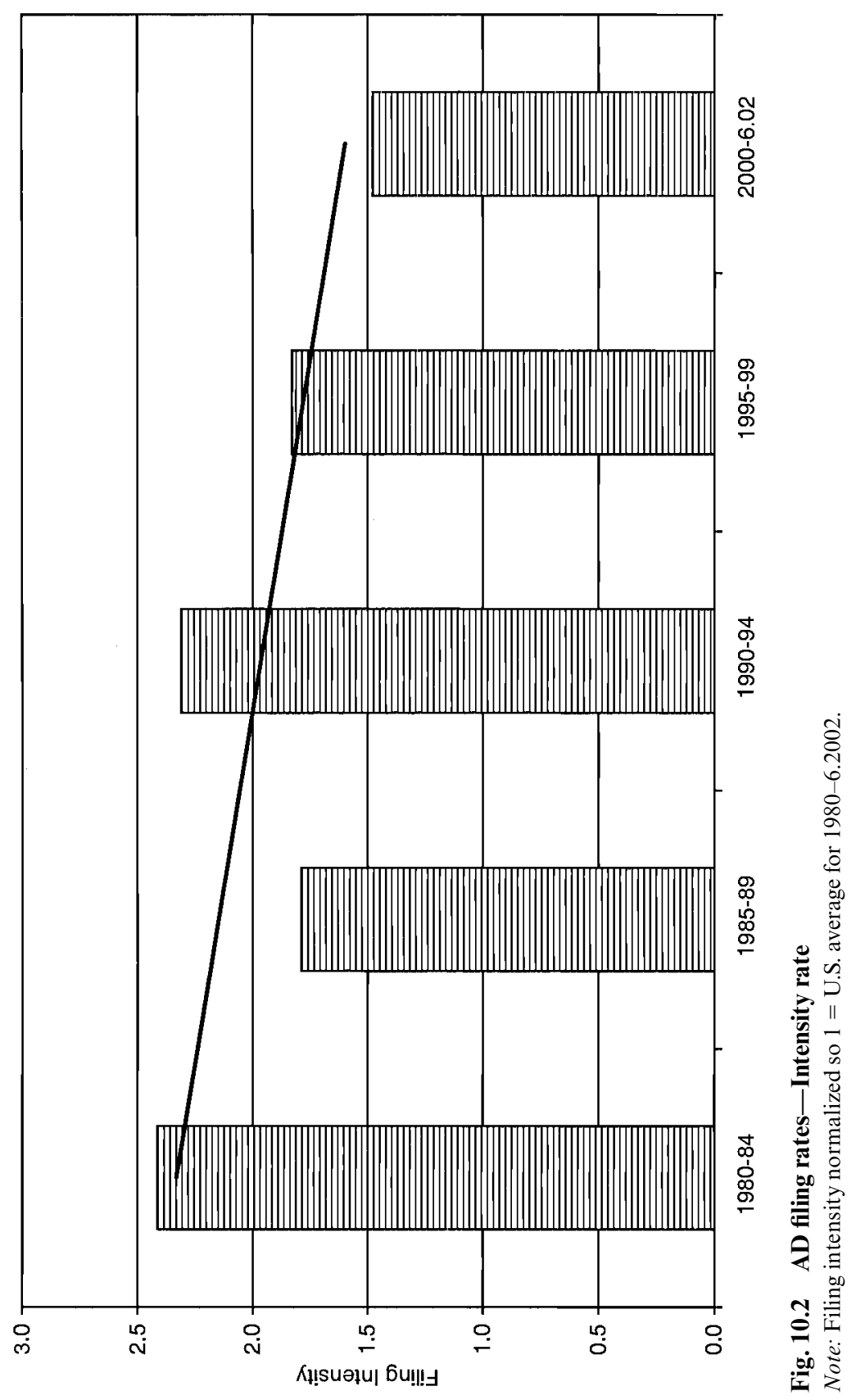




\begin{tabular}{|c|c|c|c|c|c|c|c|}
\hline & No. & Intensity & $\%$ Aff. & & No. & Intensity & $\%$ Aff. \\
\hline \multicolumn{4}{|l|}{ Americas } & \multicolumn{4}{|l|}{ East Asia and Pacific } \\
\hline United States & 904 & 1.00 & 0.60 & New Zealand & 75 & 7.42 & 0.48 \\
\hline Canada & 490 & 2.48 & 0.65 & South Korea & 74 & 0.89 & 0.64 \\
\hline Argentina & 235 & 16.79 & 0.69 & Indonesia & 43 & 10.34 & 0.60 \\
\hline Mexico & 230 & 2.75 & 0.57 & The Philippines & 22 & 2.16 & 0.55 \\
\hline Brazil & 165 & & 0.52 & Malaysia & 22 & 0.75 & 0.73 \\
\hline Peru & 37 & 12.19 & 0.65 & Thailand & 15 & 0.88 & 0.87 \\
\hline Colombia & 35 & 5.42 & 0.60 & Taiwan & 6 & 0.46 & 0.33 \\
\hline Venezuela & 31 & 5.52 & 0.74 & Japan & 6 & 0.15 & 0.67 \\
\hline Chile & 16 & 3.59 & 0.69 & PR-China & 6 & 0.61 & 0.83 \\
\hline Trinidad-Tobago & 10 & 18.06 & 0.90 & Singapore & 2 & 0.32 & 1.00 \\
\hline Costa Rica & 6 & 7.37 & 0.17 & North Korea & 0 & & \\
\hline Uruguay & 5 & 20.11 & 0.80 & Papua N. Guinea & 0 & & \\
\hline Jamaica & 3 & & 1.00 & Macao & 0 & & \\
\hline Panama & 2 & 12.45 & 1.00 & Vietnam & 0 & & \\
\hline Nicaragua & 2 & & 1.00 & Hong Kong & 0 & & \\
\hline Guatemala & 1 & 5.72 & 1.00 & \multicolumn{4}{|l|}{ Australia } \\
\hline Paraguay & 1 & & 1.00 & $\begin{array}{l}\text { Australla } \\
\text { Australia }\end{array}$ & 822 & 1232 & 037 \\
\hline Ecuador & 1 & 3.28 & 1.00 & & 822 & 12.32 & 0.31 \\
\hline El Salvador & 0 & & & \multicolumn{4}{|l|}{ South Asia } \\
\hline Honduras & 0 & & & India & 285 & 19.63 & 0.98 \\
\hline Bolivia & 0 & & & Nepal & 0 & & \\
\hline Dominican Republic & 0 & & & Sri Lanka & 0 & & \\
\hline Cuba & 0 & & & Bangladesh & 0 & & \\
\hline$E U+$ & & & & Pakistan & 0 & & \\
\hline European Community & 663 & 0.84 & 0.66 & \multicolumn{4}{|l|}{ North Africa } \\
\hline Turkey & 64 & 5.29 & 0.69 & Egypt & 33 & 8.24 & 0.91 \\
\hline Finland & 16 & 1.94 & 0.69 & Algeria & 0 & & \\
\hline Sweden & 15 & 0.97 & & Tunisia & 0 & & \\
\hline Austria & 2 & 0.58 & & Mozambique & 0 & & \\
\hline Spain & 1 & 0.65 & & Liby Arab Jm & 0 & & \\
\hline Cyprus & 0 & & & \multicolumn{4}{|l|}{ Middle East } \\
\hline Switzerland & 0 & & & Israel & 30 & & 0.633 \\
\hline Norway & 0 & & & Bahrain & 0 & & \\
\hline \multicolumn{4}{|l|}{ East Europe-Central Asia } & Oman & 0 & & \\
\hline Poland & 35 & 4.99 & 0.29 & Jordan & 0 & & \\
\hline Czechoslovakia & 3 & & 0.33 & Qatar & 0 & & \\
\hline Bulgaria & 1 & 3.97 & 1.00 & United Arab Em & 0 & & \\
\hline Fm Yugoslavia & 1 & & 0.00 & Iran & 0 & & \\
\hline Fm German Dm Rp & & & & Saudi Arabia & 0 & & \\
\hline (East) & 0 & & & \multicolumn{4}{|l|}{ East and Southern Africa } \\
\hline Hungary & 0 & & & South Africa & 173 & 16.22 & 0.71 \\
\hline Romania & 0 & & & Malawi & 0 & & \\
\hline Fm USSR & 0 & & & Kenya & 0 & & \\
\hline West Africa & & & & Zimbabwe & 0 & & \\
\hline Cote D'Ivoire & 0 & & & & & & \\
\hline
\end{tabular}


Table 10.2

Growth of AD law

\begin{tabular}{lccc}
\hline Time period & $\begin{array}{c}\text { No. countries with } \\
\text { AD statute }\end{array}$ & $\begin{array}{c}\text { No. countries filing } \\
\text { AD actions }\end{array}$ & $\begin{array}{c}\% \text { cases filed by } \\
\text { new users }\end{array}$ \\
\hline $1980-1984$ & 34 & 8 & 1 \\
$1985-1989$ & 38 & 10 & 11 \\
$1990-1994$ & 45 & 24 & 36 \\
$1995-1999$ & 61 & 32 & 61 \\
$2000-6.02$ & 87 & 30 & 60 \\
\hline
\end{tabular}

Sources: AD implementation dates, Zanardi (2004); filing rates, author's calculations.

${ }^{\mathrm{a}}$ Count at beginning of period.

of countries with their own AD statute had grown to forty-five. As of mid2002, eighty-seven countries had enacted their own AD statute.

Of course, just because a country has a statute does not necessarily imply that a country uses it. Japan, for instance, was one of the earliest adopters of $\mathrm{AD}$ protection but has rarely used it. But over the past two decades there has been a steady increase in the number of countries using $\mathrm{AD}$. The number of countries initiating AD investigations has grown from eight (in 1980-1984) to twenty-four (in 1990-1994) to thirty (2000-June 2002).

Thus the four traditional AD users (the United States, EU, Canada, and Australia) have been joined by an expanding set of new users. And the new users have not been bashful about using AD (table 10.2). The share of AD cases accounted for by new users has soared from 1 percent (in 1980-1984) to 36 percent (in 1990-1994) to 60 percent (2000-June 2002).

Differentiating between new and traditional users, I depict the number of AD cases filed (see figure 10.3) and filing intensity (see figure 10.4). Several very important lessons can be gleaned. First, while overall AD disputes are on the rise (as seen in figure 10.1) the use of AD by traditional users has slightly fallen (or at best remained flat) over the sample period. Thus, the overall growth in AD activity is entirely driven by the embrace of AD protection by new users. New users have gone from filing a handful of complaints in 1980-1984 to filing hundreds of complaints each year in the last decade. Second, in terms of intensity of usage, new users are much more prolific in their use of AD than traditional users. While traditional users have an overall filing intensity of about $1-1.5$, new users have an overall filing intensity of 3-4, more than twice the traditional users' rate. In other words, per dollar value of imports, new users file upwards of four times as many AD petitions as traditional users. Third, the role of new users is even starker when I examine the trend in filing intensity. The filing intensity for traditional users has steadily fallen over time to about 1 (i.e., the U.S. average for the entire sample). By contrast, the filing intensity of new users has grown sharply and has averaged well over 4 for the decade of 


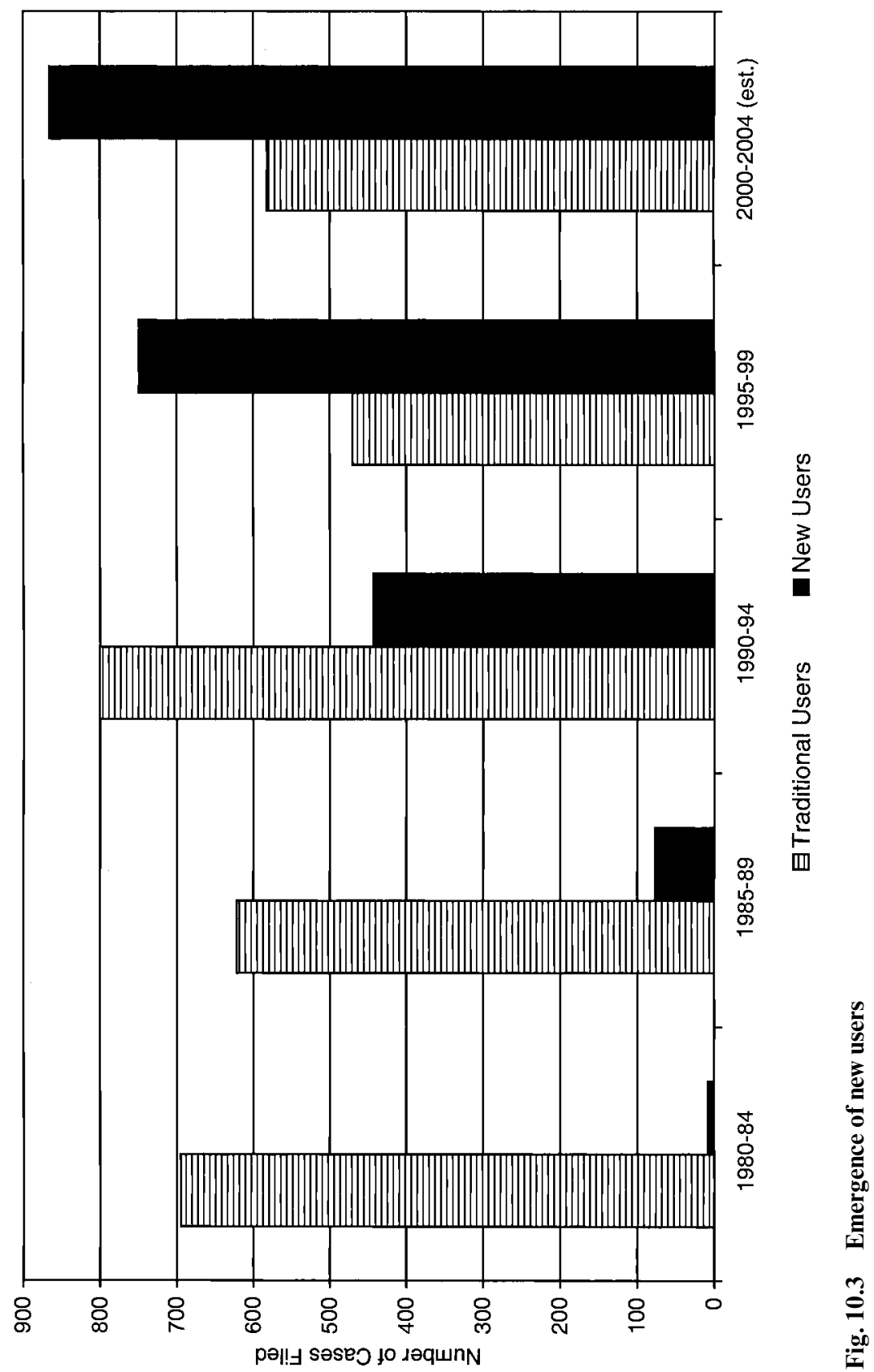




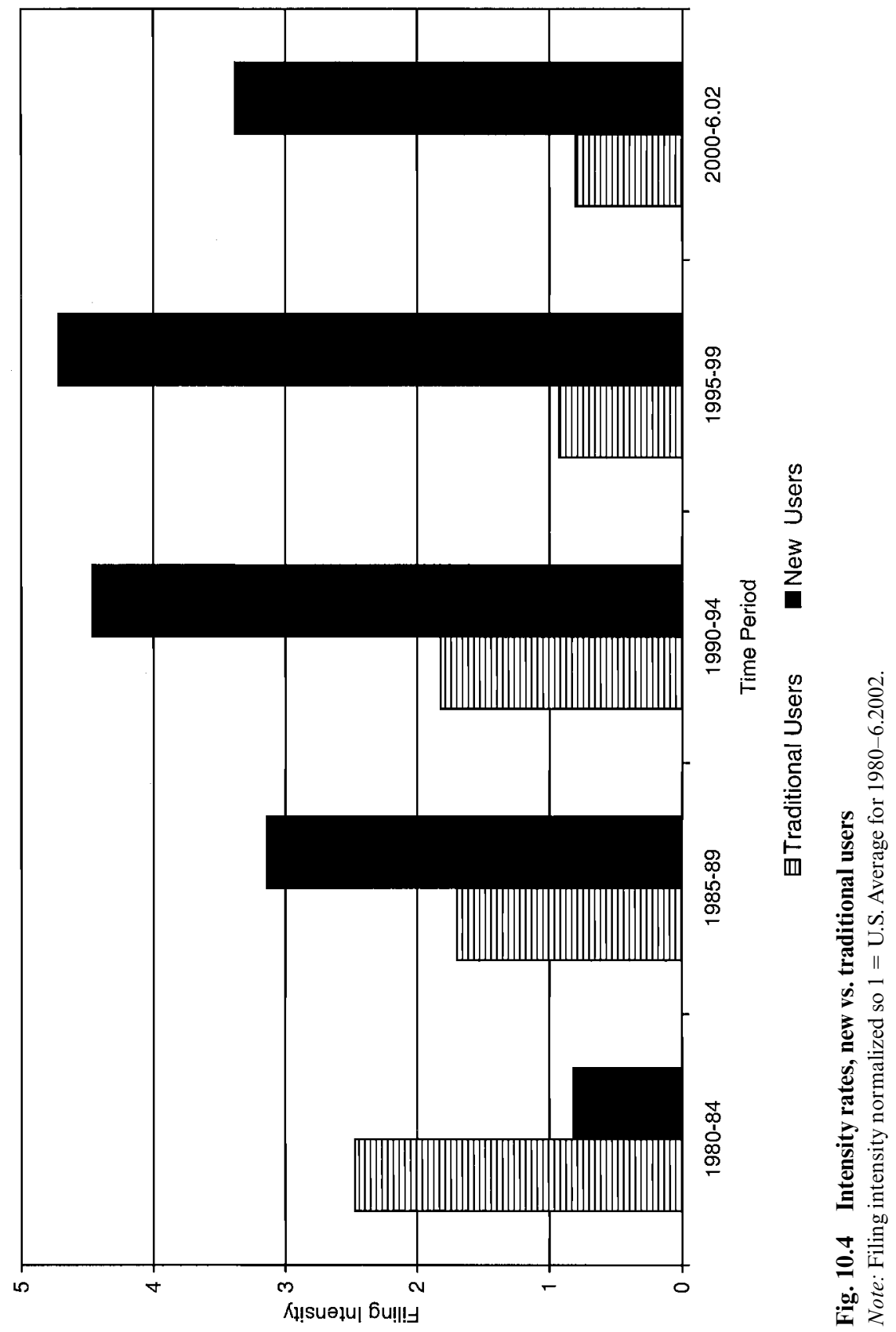


the 1990s. The view that the growth in AD activity is simply a reflection of the growth in trade is not supported from this more detailed perspective. The filing intensity of new users, the source of the growth in number of AD disputes, has easily exceeded their import growth.

Table 10.1 sheds more light on these trends by looking at the individual country filing intensity. Argentina and South Africa have a filing intensity of almost 17; India's filing intensity is almost 20. In other words, if a given value of imports induces the two biggest traditional obstacles to AD reform (the United States and EU) to file about one case, the same imports would generate fifteen-twenty cases for some of the leading new users. Such statistics make it clear that new users have embraced AD in a way unfamiliar to traditional users.

In table $10.1 \mathrm{I}$ also report the fraction of $\mathrm{AD}$ cases that ultimately result in some form of protection. ${ }^{10}$ The two biggest traditional AD users-the United States and EU - each levy duties in about two-thirds of their cases. Most of the new users also report similar statistics. This is especially the case for those that use AD more heavily such as Argentina (69 percent of cases result in duties), Mexico (57 percent), Brazil (52 percent), and South Africa (71 percent). The big outliers are India (98 percent of cases result in duties) and Egypt (91 percent). Also worth noting is the People's Republic of China, with 83 percent of its cases resulting in duties. While the People's Republic of China only had a handful of cases during my sample, there has been a sharp increase in AD activity in the People's Republic of China in the last eighteen months. In addition, public statements by People's Republic of China officials seem to indicate a very aggressive attitude.

How should one interpret the prolific rate that new users have filed AD complaints? It seems to me there are several possibilities. Such trends could lead one to wonder that there is something unfair about the way AD law is currently written. Perhaps they might even lead to one to conclude (as I argued previously) that the AD system itself makes little economic sense and is simply thinly disguised protectionism.

Or, alternatively, if one is committed to the belief that AD simply levels the playing field and that AD rules as currently written are an acceptable way to promote fair trade, then one might conclude that for some reason exporters price particularly unfairly when selling to new users. This is a slightly uncomfortable position, as one must further explain why exporters who have been successful in many other markets must resort to unfair pricing when servicing the new users.

The most likely interpretation, especially by the traditional users such as the United States and EU, is that AD rules are correct but that new users are implementing the rules incorrectly. This final reading, however, is

10. Statistics on the size of dumping margins would also be a useful indicator of how AD use varies across countries. Unfortunately, such data is not generally available. 
somewhat tenuous. To begin with, almost all of the new users have based their AD rules on either the U.S. or EU system. In most cases, the language of the rules is like language of the United States and EU; vague language and vast amounts of discretion characterize all countries' AD statutes. While there appears to some anecdotal evidence that some new users are even more casual in their dumping calculations, proving this assertion requires a careful case-by-case examination. In addition, the decided majority (about two-thirds) of WTO disputes involving AD actions have been aimed at actions of the traditional users, not new users. This suggests that $\mathrm{AD}$ use by traditional users has caused more rancor than $\mathrm{AD}$ use by new users. Moreover, new users have fared about the same as traditional users in these proceedings, each having about 50 percent of the claims accepted by the dispute panel (Durling 2003). At face value, it is not obvious that new users abuse $\mathrm{AD}$ rules to any greater degree than traditional users. Current $\mathrm{AD}$ rules are inherently flexible. The fact that the same set of facts leads India to find injury but might lead the United States to reject the case does not mean that India has violated the AD agreement. Finally, getting the new users to adopt different rules for their $\mathrm{AD}$ proceedings means that the traditional users will have to put AD rules on the agenda. While the United States reluctantly agreed to do so, its willingness to sincerely negotiate restraining $\mathrm{AD}$ is highly doubtful. Among many members of the U.S. Congress, for example, the current AD system is sacrosanct and even modest revisions to AD rules could jeopardize the whole agreement. ${ }^{11}$

\subsection{AD and East Asian and South Asian Countries}

\subsubsection{General Trends-How Often Are They Targeted?}

I now turn to the question of who has been subject to AD investigations. In table 10.3 I tabulate AD activity by region, where I have grouped according to the World Bank definitions with one exception. Given its longstanding use of $\mathrm{AD}$, I pulled Australia from its standard World Bank region designation "East Asia and Pacific." Most of the other groupings are pretty self-explanatory: the "Americas" includes Canada, the United States, and countries in Latin and South America; "EU+" includes the EU, European Fair Trade Association (EFTA) countries, Turkey, and so on.

11. On November 7, 2001 the U.S. House of Representatives passed a resolution instructing the President to "preserve the ability of the United States to enforce rigorously its trade laws, including the antidumping and countervailing duty laws, and avoid agreements which lessen the effectiveness of domestic and international disciplines on unfair trade, especially dumping and subsidies" (http://www.thomas.loc.gov). Similarly, in May 2002 the Senate passed the Dayton-Craig amendment that would require that any Doha Round agreements to change the unfair trade provisions of the WTO be subject to a separate vote apart from the rest of the agreement. 
No. AD actions (all users)

\begin{tabular}{|c|c|c|c|c|c|}
\hline & 1980-1984 & 1985-1989 & 1990-1994 & 1995-1999 & $2000-6.02$ \\
\hline \multicolumn{6}{|c|}{ Against all countries/regions } \\
\hline \multicolumn{6}{|l|}{ Initiating region } \\
\hline Americas & 332 & 368 & 645 & 479 & 350 \\
\hline East and Southern Africa & 0 & 0 & 16 & 129 & 28 \\
\hline East Asia and Pacific & 0 & 17 & 66 & 129 & 59 \\
\hline East Europe-Central Asia & 0 & 0 & 24 & 12 & 4 \\
\hline Middle East & 0 & 0 & 3 & 21 & 6 \\
\hline North Africa & 0 & 0 & 0 & 24 & 9 \\
\hline EU+ & 133 & 132 & 215 & 193 & 88 \\
\hline South Asia & 0 & 0 & 15 & 131 & 139 \\
\hline West Africa & 0 & 0 & 0 & 0 & 0 \\
\hline Australia & 238 & 182 & 260 & 101 & 41 \\
\hline Total & 703 & 699 & 1,244 & 1,219 & 724 \\
\hline Percent by Asia-Pacific & 0 & 2 & 7 & 21 & 27 \\
\hline Percent by Asia-Pacific (less India) & 0 & 2 & 5 & 11 & 8 \\
\hline \multicolumn{6}{|c|}{ Initiated by all countries/regions } \\
\hline Affected region & & & & & \\
\hline Americas & 144 & 157 & 259 & 189 & 99 \\
\hline East and Southern Africa & 4 & 6 & 15 & 24 & 21 \\
\hline East Asia and Pacific & 205 & 256 & 461 & 524 & 337 \\
\hline East Europe-Central Asia & 96 & 115 & 166 & 157 & 79 \\
\hline Middle East & 6 & 9 & 11 & 17 & 20 \\
\hline North Africa & 1 & 0 & 5 & 8 & 6 \\
\hline $\mathrm{EU}+$ & 241 & 151 & 272 & 242 & 122 \\
\hline South Asia & 3 & 3 & 48 & 51 & 34 \\
\hline West Africa & 0 & 0 & 2 & 0 & 0 \\
\hline Australia & 3 & 2 & 5 & 7 & 6 \\
\hline Total & 703 & 699 & 1,244 & 1,219 & 724 \\
\hline Percent by Asia-Pacific & 30 & 37 & 41 & 47 & 51 \\
\hline Percent by Asia-Pacific (less PRC) & 26 & 34 & 29 & 34 & 36 \\
\hline
\end{tabular}

Note: Countries classified into regions using World Bank system.

Let's begin by looking at table 10.3. In the top panel I tabulate by initiations by region against all countries. In the bottom panel I tabulate "affected" or "named" countries by region for cases filed by all countries. As one can see, the Americas are the leading users of AD followed by EU+ and Australia (top panel). Not coincidentally, these are the locations of the big four traditional users. Interestingly, the Americas and EU+ are also among the leading subjects of $\mathrm{AD}$ investigations (bottom panel).

At the bottom of table 10.3 I give the total cases against the Asia-Pacific and South Asia regions. Largely because of their exporting success, AsiaPacific countries such as Japan, Taiwan, and South Korea have long been singled out in the rhetoric justifying AD protection. Mastel (1998) and Co- 
hen, Blecker, and Whitney (2003) justify AD because it is the only policy available to remedy the anticompetitive effects of the (perceived) closed nature of Asian markets; or in their language, the anticompetitive effects of "sanctuary markets" and "foreign cartels."

As shown, a growing fraction of AD cases have been aimed against Asian markets, starting from 30 percent in the early 1980s and rising to about 50 percent in recent years. A big part of the increase is due to the integration of the People's Republic of China into the world trading system. In recent years about 20 percent of all AD cases target the People's Republic of China. Because the rules involving the People's Republic of China (and all nonmarket economies) differ from other Asia-Pacific countries, it makes sense if we break out the People's Republic of China cases. Once I drop the cases against the People's Republic of China, we see that the fraction of traditional user AD cases against Asia-Pacific countries has been fairly stable, averaging about one-third of the total.

The relatively stable pattern of use against Asia-Pacific countries begs the question of whether the pattern of filings is stable for both traditional and new users or whether traditional users activity against Asia-Pacific countries is declining and is being replaced by an upsurge in complaints by new users. To get at this issue, I tabulate AD filings breaking out new and traditional users (see table 10.4). The fraction of AD cases by traditional users against Asia-Pacific countries (less the People's Republic of China [PRC]) is even more stable than the overall trend. By contrast, the fraction of AD cases by new users against Asia-Pacific countries (less PRC) has grown fairly steadily over time, from 13 percent in 1980-1984 to 22 percent in 1990-1994 to 37 percent in 2000-June 2002. This is another indication that the proliferation of $\mathrm{AD}$ has adversely affected Asian countries.

\subsubsection{General Trends-How Often Do They File Cases?}

While the growth in AD activity against Asia-Pacific countries is notable, more impressive is the pattern of use by Asia-Pacific countries. As shown in table 10.3, Asia-Pacific countries accounted for no AD disputes in the early 1980s, and by the early 1990s they accounted for only 7 percent of all AD disputes. In recent years, however, use by Asia-Pacific countries has soared, and they now account for more than one-quarter of all disputes. It is important to point out, however, that India is by far the biggest source of AD activity in the Asia-Pacific region. In fact, India is quickly emerging as the leading user of $\mathrm{AD}$ in the entire world. If I drop cases initiated by India, the upward trend in AD activity by Asia-Pacific countries is still present but not nearly so stark: Asia-Pacific countries (less PRC) accounted for 0 percent of all AD activity in 1980-1984, 5 percent in 19901994, and 8 percent in 2000-June 2002.

In table 10.5 I detail AD activity focusing solely on the Asia-Pacific region. What is striking is the high percentage of cases within the region. 
Number of AD actions (new and traditional users)

\begin{tabular}{|c|c|c|c|c|c|}
\hline & $1980-1984$ & 1985-1989 & 1990-1994 & 1995-1999 & $2000-6.02$ \\
\hline \multicolumn{6}{|c|}{ Initiated by new users } \\
\hline \multicolumn{6}{|l|}{ Affected region } \\
\hline Americas & 0 & 23 & 126 & 139 & 67 \\
\hline East and Southern Africa & 0 & 0 & 4 & 12 & 9 \\
\hline East Asia and Pacific & 1 & 14 & 149 & 299 & 212 \\
\hline East Europe-Central Asia & 1 & 22 & 60 & 95 & 35 \\
\hline Middle East & 0 & 0 & 1 & 7 & 16 \\
\hline North Africa & 0 & 0 & 0 & 4 & 0 \\
\hline EU+ & 6 & 16 & 80 & 165 & 73 \\
\hline South Asia & 0 & 1 & 19 & 22 & 16 \\
\hline West Africa & 0 & 0 & 2 & 0 & 0 \\
\hline Australia & 0 & 1 & 2 & 6 & 5 \\
\hline Total & 8 & 77 & 443 & 749 & 433 \\
\hline \multicolumn{6}{|l|}{ New users } \\
\hline$\%$ against Asia-Pacific & 13 & 19 & 38 & 43 & 53 \\
\hline$\%$ against Asia-Pacific (less PRC) & 13 & 17 & 22 & 28 & 37 \\
\hline \multicolumn{6}{|c|}{ Initiated by traditional users } \\
\hline \multicolumn{6}{|l|}{ Affected region } \\
\hline Americas & 144 & 134 & 133 & 50 & 32 \\
\hline East and Southern Africa & 4 & 6 & 11 & 12 & 12 \\
\hline East Asia and Pacific & 204 & 242 & 312 & 225 & 125 \\
\hline East Europe-Central Asia & 95 & 93 & 106 & 62 & 44 \\
\hline Middle East & 6 & 9 & 10 & 10 & 4 \\
\hline North Africa & 1 & 0 & 5 & 4 & 6 \\
\hline $\mathrm{EU}+$ & 235 & 135 & 192 & 77 & 49 \\
\hline South Asia & 3 & 2 & 29 & 29 & 18 \\
\hline West Africa & 0 & 0 & 0 & 0 & 0 \\
\hline Australia & 3 & 1 & 3 & 1 & 1 \\
\hline Total & 695 & 622 & 801 & 470 & 291 \\
\hline \multicolumn{6}{|l|}{ Traditional users } \\
\hline$\%$ against Asia-Pacific & 30 & 39 & 43 & 54 & 49 \\
\hline$\%$ against Asia-Pacific (less PRC) & 26 & 36 & 33 & 42 & 34 \\
\hline Total cases- $\%$ by new users & 1 & 11 & 36 & 61 & 60 \\
\hline
\end{tabular}

Note: Traditional users are United States, EU, Australia, and Canada.

Specifically, about two-thirds of the AD cases initiated by Asia-Pacific countries are aimed at other Asia-Pacific countries. This result is consistent with previous findings showing evidence of "club behavior" (Prusa and Skeath 2004); in effect, it appears that countries often aim AD protection against trading partners who are similar. At first glance, this result seems odd as it seems to suggest countries are more likely to unfairly dump in nearby markets or in markets where they have substantial economic ties. But as I will discuss in the following, what this result really re- 
No. AD actions (Asia-Pacific focus)

\begin{tabular}{|c|c|c|c|c|c|}
\hline & 1980-1984 & 1985-1989 & 1990-1994 & 1995-1999 & $2000-6.02$ \\
\hline \multicolumn{6}{|c|}{ Against Asia-Pacific only } \\
\hline \multicolumn{6}{|l|}{ Initiating region } \\
\hline Americas & 89 & 131 & 221 & 181 & 150 \\
\hline East and Southern Africa & 0 & 0 & 3 & 55 & 16 \\
\hline East Asia and Pacific & 0 & 11 & 47 & 82 & 45 \\
\hline East Europe-Central Asia & 0 & 0 & 0 & 5 & 0 \\
\hline Middle East & 0 & 0 & 0 & 2 & 0 \\
\hline North Africa & 0 & 0 & 0 & 8 & 4 \\
\hline EU+ & 15 & 49 & 106 & 128 & 43 \\
\hline South Asia & 0 & 0 & 9 & 64 & 85 \\
\hline West Africa & 0 & 0 & 0 & 0 & 0 \\
\hline Australia & 104 & 68 & 123 & 50 & 28 \\
\hline Total & 208 & 259 & 509 & 575 & 371 \\
\hline Percent Intra-Asia-Pacific & 0 & 0 & 2 & 21 & 27 \\
\hline \multicolumn{6}{|c|}{ Initiated by Asia-Pacific only } \\
\hline \multicolumn{6}{|l|}{ Affected region } \\
\hline Americas & 0 & 0 & 10 & 18 & 13 \\
\hline East and Southern Africa & 0 & 0 & 1 & 3 & 3 \\
\hline East Asia and Pacific & 0 & 11 & 51 & 140 & 121 \\
\hline East Europe-Central Asia & 0 & 0 & 2 & 40 & 7 \\
\hline Middle East & 0 & 0 & 0 & 2 & 13 \\
\hline North Africa & 0 & 0 & 0 & 0 & 0 \\
\hline $\mathrm{EU}+$ & 0 & 5 & 12 & 49 & 31 \\
\hline South Asia & 0 & 0 & 5 & 6 & 9 \\
\hline West Africa & 0 & 0 & 0 & 0 & 0 \\
\hline Australia & 0 & 1 & 0 & 2 & 1 \\
\hline Total & 0 & 17 & 81 & 260 & 198 \\
\hline Percent Intra-Asia-Pacific & & 65 & 69 & 56 & 66 \\
\hline
\end{tabular}

veals is that antidumping charges are driven by characteristics of the local economy.

\subsubsection{Industry Pattern}

The similarity in filing patterns by new and traditional users supports the notion that it is characteristic of the Asia-Pacific economies that drive AD protection. Perhaps new and traditional users alike feel Asia-Pacific home markets are closed, which allows their firms to price unfairly low in export markets. While I have no evidence directly contradicting this view, the position would be more credible if the same industries were subject to AD investigations.

To address this issue, I examined the use of AD by industry. In table 10.6 I report case initiations for the top industries (in the top panel of the table). 


\begin{tabular}{lcc}
\hline & All Others & Asia-Pacific \\
\hline $\begin{array}{l}\text { Initiating industries } \\
\text { Iron and steel basic industries }\end{array}$ & 23.0 & 12.2 \\
Manufacture of basic industrial chemicals except fertilizers & 10.9 & 23.4 \\
Manufacture of synthetic resins, plastic materials and & & \\
$\quad$ man-made fibres except glass & 7.8 & 11.3 \\
Manufacture of fabricated metal products except machinery & & \\
$\quad$ and equipment, nec & 5.3 & 0.9 \\
Machinery and equipment except electrical, nec & 3.1 & 2.2 \\
Spinning, weaving and finishing textiles & 2.8 & 8.1 \\
Manufacture of pulp, paper and paperboard & 2.4 & 5.4 \\
Manufacture of glass and glass products & 2.1 & 1.6 \\
Manufacture of electrical industrial machinery and apparatus & 2.1 & 0.0 \\
Manufacture of textiles not elsewhere classified & 1.9 & 1.4 \\
Affected industries & & \\
Iron and steel basic industries & 27.5 & 13.6 \\
Manufacture of basic industrial chemicals except fertilizers & 13.5 & 11.0 \\
Manufacture of synthetic resins, plastic materials and & & \\
$\quad$ man-made fibres except glass & 8.1 & 8.4 \\
Manufacture of fabricated metal products except machinery & & \\
$\quad$ and equipment, nec & 4.0 & 5.9 \\
Manufacture of pulp, paper and paperboard & 3.7 & 1.5 \\
Machinery and equipment except electrical, nec & 3.2 & 2.8 \\
Manufacture of drugs and medicines & 2.4 & 2.4 \\
Spinning, weaving and finishing textiles & 2.4 & 4.8 \\
Manufacture of electrical industrial machinery and apparatus & 2.2 & 1.4 \\
Manufacture of fertilizers and pesticides & 2.2 & 0.6 \\
\hline
\end{tabular}

I separate the filings by "Asia-Pacific" countries and by "All other" users. In the bottom panel I report affected industries.

The industries are ordered by use by "All other" countries. As seen, there are some similarities between the two lists, but more interesting are the differences. For instance, the steel industry accounts for a lot of AD disputes in most parts of the world. For instance, "Iron and steel basic industries" and "Manufacture of fabricated metal products" account for about 28 percent of AD filings (top panel of the table); these are predominately due to filings by the EU and the United States. However, the steel industry accounts for only 13 percent of Asia-Pacific filings. While this is a sizeable fraction, it is only half the "All others" total.

This suggests that it must be the Asia-Pacific steel mills that are the preeminent dumpers; but as shown in the bottom panel of the table, the steel industry accounts for far fewer Asia-Pacific disputes than for the other regions in the world. In other words, the steel industry outside the AsiaPacific region uses $\mathrm{AD}$ to restrict trade from all sources. It does not solely target, or even disproportionately target, Asia-Pacific sources. This is evi- 
AD Filings Against Asia-Pacific Countries; leading industries (ISIC, Rev 2)

\begin{tabular}{|c|c|c|c|c|}
\hline & \multicolumn{2}{|c|}{ New Users } & \multicolumn{2}{|c|}{ Traditional Users } \\
\hline & Percent & Rank & Percent & Rank \\
\hline $\begin{array}{l}\text { Manufacture of basic industrial chemicals } \\
\text { except fertilizers }\end{array}$ & 14 & 1 & 9 & 2 \\
\hline Iron and steel basic industries & 10 & 2 & 16 & 1 \\
\hline $\begin{array}{l}\text { Manufacture of synthetic resins, plastic materials } \\
\text { and man-made fibres except glass }\end{array}$ & 8 & 3 & 8 & 3 \\
\hline Spinning, weaving and finishing textiles & 7 & 4 & 4 & 6 \\
\hline Manufacture of textiles, nec & 4 & 5 & 2 & 15 \\
\hline $\begin{array}{l}\text { Manufacture of electrical apparatus and } \\
\text { supplies, nec }\end{array}$ & 4 & 6 & 2 & 10 \\
\hline Manufacture of drugs and medicines & 4 & 7 & 2 & 20 \\
\hline Tire and tube industries & 4 & 8 & 1 & 27 \\
\hline $\begin{array}{l}\text { Manufacture of footwear, except vulcanized or } \\
\text { moulded rubber or plastic footwear }\end{array}$ & 3 & 9 & 1 & 34 \\
\hline Manufacture of motorcycles and bicycles & 3 & 10 & 1 & 23 \\
\hline Manufacture of chemical products, nec & 3 & 11 & 3 & 7 \\
\hline Manufacture of glass and glass products & 3 & 12 & 3 & 8 \\
\hline $\begin{array}{l}\text { Manufacture of fabricated metal products } \\
\text { except machinery and equipment, nec }\end{array}$ & 3 & 13 & 8 & 4 \\
\hline
\end{tabular}

dence that $\mathrm{AD}$ often tells us more about the users than it does about the targets. The U.S. steel industry is often cited as an industry that has fallen behind their international competitors. ${ }^{12}$

The chemical industry is also an active user of AD. It is the leading industry among Asia-Pacific nations. The textiles industry (synthetic and natural) accounts for about 20 percent of Asia-Pacific AD disputes. By contrast, these industries are far less significant users for other nations.

In the bottom panel of table 10.6 I report industries targeted in AD actions. As was seen in the top panel, the industry breakdown differs between Asia-Pacific nations and others. To further analyze the cases against AsiaPacific nations, in table 10.7 I report cases by new and traditional users. In this table I sort the list of top industries filed by new users. The industry most commonly investigated by new users is the chemical industry; it is the second most commonly investigated by traditional users. While the top three industries are the common across new and traditional users, after these three industries the two lists diverge substantially. The fifth most common industry among new users (Manufacture of textiles) is number fifteen among traditional users. The seventh most common industry among

12. The United States essentially made this claim in their 2001 petition for safeguard protection, arguing that they needed time to restructure and retool. 
new users (manufacture of drugs and medicines) is number twenty among traditional users. The eighth most common industry among new users (tire and tube industries) is number twenty-seven among traditional users.

\subsection{Macroeconomic Determinants of New and Traditional User Antidumping Activity}

Knetter and Prusa (2003) provide an econometric analysis of the AD filing patterns of the four traditional users. They analyzed how macroeconomic factors in general, and fluctuations in real exchange rates in particular, can affect the determination of each of these criteria. I now extend that analysis and examine whether there is any difference in filing behavior between traditional and new users.

As explained in Knetter and Prusa (2003), a foreign firm's responses to a real exchange rate changes increases the likelihood that at least one of the AD criteria will be satisfied. At a theoretical level, real exchange rate changes can either increase or decrease filings, depending on which AD test is most responsive to pricing changes. They explain is that when the foreign currency weakens, the firm's costs (denominated in domestic currency units) fall. Therefore, normal response of foreign firms is to lower the domestic currency price of foreign goods. This would be expected to reduce the profits of domestic producers in the same industry by lowering their margins or market share. ${ }^{13}$ They then note that in general this price response (in terms of its own home currency) implies that the foreign firm has increased the foreign currency price of shipments to the domestic market relative to other destinations but by less than the appreciation of the domestic currency. An increase in the foreign currency price of shipments to the domestic market obviously reduces the chance that the foreign firm is guilty of price-based dumping. Thus, with typical pricing-to-market behavior, a strong (weak) domestic currency will increase (decrease) the chance of injury and make it less (more) likely that the foreign firm is guilty of dumping pricing. If I presume that the incentive to file an AD case is positively related to the likelihood of affirmative decisions on the injury and dumping criteria, then in theory it is entirely possible that either exchange rate appreciations or depreciations can precipitate AD filings.

Empirically which effect is more important is also an open question. In particular, using a data set based on U.S. AD filings from 1982 to 1987, Feinberg (1989) finds that filings increase with a weaker dollar. By con-

13. Note that the dollar price of imported goods will fall relative to domestic goods with a real appreciation of the dollar provided the foreign firm does not completely offset the relative cost change with a markup change. The special case in which markups are adjusted to fully offset the effects of currency movements is known as "complete pricing-to-market" in the literature. The opposite case, in which exchange rate changes are fully passed through to foreign buyers, is known as "full pass-through." 
trast, using a more comprehensive data set (more countries, longer time series), Knetter and Prusa (2003) find the opposite result: filings increase with a weaker domestic currency.

Fluctuations in economic activity, both in the importing country and the exporting country, might also affect filing decisions. Clearly, a slump in economic activity in the importing country makes it more likely domestic firms perform poorly, which may facilitate a finding of material injury. Also, a weak economy in the importing country might naturally lead foreign firms to reduce prices on shipments to the importing country. This could increase the likelihood of pricing below fair value. Thus I would expect that import country GDP will be negatively related to filings. It is less clear how export-country GDP is related to filings. One possibility is that a weak foreign economy increases the likelihood that foreign firms will cut prices to maintain overall levels of output. While such behavior might cause injury to domestic firms, it is not clear that it would trigger pricing below "fair value" in the price-based sense, as foreign firms would presumably be lowering prices to all markets (especially their own home market).

The World Bank's World Development Indicators provided real GDP data and imports for nearly every country involved in an AD dispute. In the empirical analysis I analyze the number of filings against individual countries. I therefore gathered bilateral real exchange rates between each of the filing countries and each country named in at least one AD case since 1980. The Economic Research Service of the U.S. Department of Agriculture was a convenient source for bilateral real exchange rates as they report exchange rates in a consistent fashion for virtually all countries in the world. The exchange rate is defined as foreign currency per unit of domestic currency so that an increase in the exchange rate reflects an appreciation of the filing country's currency.

Following Knetter and Prusa (2003), I estimate the panel data where I conjecture that the number of cases against an affected country by a filing country in each year is a function of the bilateral real exchange rate, filing country real GDP growth. In some specifications I also include the real value of imports from the affected country in order to investigate the extent to which AD filings are driven by import trends.

Because the number of filings is a nonnegative count variable, I will estimate the relationship between number of filings and macroeconomic factors using negative binomial regression, which is essentially a Poisson model with a more flexible error structure. Following Knetter and Prusa (2003), I normalize the real exchange rate variable by dividing each exchange rate series by its sample mean before taking logs. As discussed in Knetter and Prusa, countries generally analyze pricing behavior over the year prior to the filing of the case in order to assess dumping. By contrast, countries generally evaluate injury over a longer time horizon, often over 
the three years preceding the filing. As a result, I report results with a oneyear lag on the real exchange rate and three-year lags on real GDP growth and imports.

I report "incidence rate ratios" associated with the parameter estimates. The incidence rate ratio (IRR) is the ratio of the counts predicted by the model when the variable of interest is one unit above its mean value and all other variables are at their means to the counts predicted when all variables are at their means. Thus, if the IRR for the real exchange rate is 1.50 , then a one-unit increase in the real exchange rate (a 100 percent real appreciation given that I use the log of the real rate) would increase counts by 50 percent when all other variables are at their means. The $t$-statistics are reported for a test of the null hypothesis that the IRR $=1$, which would imply no relationship between the dependent variable and the regressor.

In table 10.8 I present results using all observations on new and traditional user AD activity. The estimated impact for new users is just the base IRR, but for traditional users one needs to add the base IRR to the "traditional user" IRR. For example, in the model the IRR for the real exchange rate for traditional users is $1.65(\exp \ln [1.12]+\ln [1.47]=1.65)$.

I first note that the results (for all model specifications) confirm the Knetter-Prusa (2003) findings - namely, that domestic currency appreciation unambiguously lead to an increase in AD filings. Second, I note that the exchange rate has a much smaller impact for new users (an IRR of 1.12 versus 1.65 for traditional users). This implies that the real exchange is particularly important for the injury determination for traditional users. One interpretation of this finding is that the injury standard is sufficiently weak

Table 10.8 Negative binomial estimation of bilateral filings: Traditional versus new users

\begin{tabular}{lcccc}
\hline Model & $(1)$ & $(2)$ & $(3)$ & $(4)$ \\
\hline rxr $(-1)$ & 1.115 & 1.184 & 1.233 & 1.167 \\
& $(3.12)^{* * *}$ & $(3.17)^{* * *}$ & $(4.08)^{* * *}$ & $(2.90)^{* * *}$ \\
rxr $(-1)$ - traditional user & 1.471 & 1.146 & 1.128 & 1.138 \\
& $(4.22)^{* * *}$ & $(1.27)$ & $(1.15)$ & $(1.20)$ \\
Growth imports & & & 1.241 & 1.264 \\
& & & $(3.86)^{* * *}$ & $(4.09)^{* * *}$ \\
Growth imports - traditional user & & & 0.954 & 0.879 \\
Growth GDP & & 0.823 & $(0.65)$ & $(1.74)$ \\
& & $(0.44)$ & & 0.588 \\
Growth GDP - traditional user & & 0.964 & & $1.18)$ \\
& & $(0.08)$ & & 1.377 \\
Observations & 6,835 & 4,804 & 4,947 & 4,799 \\
\hline
\end{tabular}

Note: Absolute value of $z$-statistics in parentheses.

*** Significant at the 1 percent level. 
for new users that there is no need for import competing industries can win their claim with little regard for the strength of the currency.

Domestic GDP growth is negatively related to filings, but the impact is not statistically significant. Once again, this finding confirms what Knetter and Prusa (2003) found. In contrast with the exchange rate, however, I do not find any significant difference between new and traditional users.

Finally, I also include specifications with the growth in imports over the prior three years. Here I find the import growth has about the same impact on AD filings by new users (an IRR of 1.23) but has almost no impact on filings by traditional users (an IRR of about 1.39).

In table 10.9 I compare the traditional users with just East Asian and South Asian countries. Qualitatively, the results are very much similar to those in table 10.8; specifically, the results indicate a real exchange rate appreciation stimulates AD activity. Interestingly, the magnitude of the impact for East Asian (South Asian) countries is smaller (larger) than for traditional users. For both regions, however, the difference is not statistically significant.

Finally, I again see that import growth stimulates AD disputes, especially for India (South Asia) and the impact is almost three times as large

\begin{tabular}{|c|c|c|c|c|}
\hline $\begin{array}{l}\text { Negative } \\
\text { Asian us }\end{array}$ & ial estimat & of bilateral & s: Tradition & \\
\hline Model & (1) & (2) & (3) & (4) \\
\hline $\operatorname{rxr}(-1)$ & $\begin{array}{l}1.358 \\
(3.35)^{* * *}\end{array}$ & $\begin{array}{l}1.356 \\
(3.93)^{* * *}\end{array}$ & $\begin{array}{l}1.392 \\
(3.68)^{* * * *}\end{array}$ & $\begin{array}{l}1.327 \\
(3.09)^{* * *}\end{array}$ \\
\hline $\operatorname{rxr}(-1)-$ East Asia & $\begin{array}{r}0.857 \\
(0.77)\end{array}$ & & $\begin{array}{c}0.841 \\
(0.87)\end{array}$ & $\begin{array}{c}0.879 \\
(0.64)\end{array}$ \\
\hline $\operatorname{rxr}(-1)-$ South Asia & $\begin{array}{l}1.344 \\
(0.96)\end{array}$ & & $\begin{array}{c}1.112 \\
(0.36)\end{array}$ & $\begin{array}{c}0.986 \\
(0.05)\end{array}$ \\
\hline Growth imports & & & $\begin{array}{l}1.189 \\
(3.93)^{* * *}\end{array}$ & $\begin{array}{c}1.114 \\
(2.37)^{* *}\end{array}$ \\
\hline Growth imports - East Asia & & & $\begin{array}{c}0.892 \\
(1.01)\end{array}$ & $\begin{array}{c}0.952 \\
(0.42)\end{array}$ \\
\hline Growth imports - South Asia & & & $\begin{array}{l}2.221 \\
(3.18)^{* * *}\end{array}$ & $\begin{array}{l}2.881 \\
(3.47)^{* * * *}\end{array}$ \\
\hline Growth GDP & $\begin{array}{c}0.767 \\
(2.43)^{* *}\end{array}$ & $\begin{array}{l}0.753 \\
(2.52)^{* *}\end{array}$ & & $\begin{array}{l}0.777 \\
(2.26)^{* *}\end{array}$ \\
\hline Growth GDP - East Asia & $\begin{array}{c}0.458 \\
(1.18)\end{array}$ & & & $\begin{array}{c}0.42 \\
(1.30)\end{array}$ \\
\hline Growth GDP - South Asia & $\begin{array}{l}1.636 \\
(0.37)\end{array}$ & & & $\begin{array}{c}0.131 \\
(1.36)\end{array}$ \\
\hline Observations & 3,418 & 3,418 & 3,550 & 3,418 \\
\hline
\end{tabular}

Note: Absolute value of $z$-statistics in parentheses.

*** Significant at the 1 percent level.

** Significant at the 5 percent level. 
as for traditional users. Such a large estimate could be interpreted in more than one way. On the one hand, it might simply reflect a huge increase in unfair trade activity. On the other hand, given the earlier discussion, it is more plausible to interpret this as a sign that AD protection often emerges as a country liberalizes its tariffs and quotas. In the case of India, for instance, during the 1990s tariffs fell by about one-half. The natural response for import-competing industries is to turn to AD to restore the previous level of protection.

\subsection{Concluding Comments}

Overall, the long-run trend in AD use is a serious concern for the world trading system. The data presented in this paper make it clear that AD has long been the leading administered trade barrier, and its growth over the past two decades now makes AD the standout. On average, AD filings have grown about 36 percent in each of the past two decades. What is perhaps the most troubling aspect of this growth is that most of the growth in AD activity over the past fifteen years has been due to use by countries who previously never even had an AD statute on their books. These new users have embraced AD enthusiastically, with filing rate fifteen-twenty times those of the traditional users. ${ }^{14}$

Asia-Pacific nations have been significantly affected by the proliferation of AD. They have been frequent targets of $\mathrm{AD}$ actions by traditional users, and the rhetoric justifying $\mathrm{AD}$ protection subtly and not so subtly alludes to U.S. and European fears about competing with Asian economies. Even if the People's Republic of China is excluded, Asia-Pacific economies have accounted for about one-third of all AD cases.

It is important to recognize, however, that it is the proliferation of $\mathrm{AD}$ that is the current driving force behind $\mathrm{AD}$ actions. As depicted in figure 10.5, the number of cases against Asia-Pacific nations by traditional users has declined over the past decade. So while the total number of AD disputes against Asia-Pacific has risen, the source of the trade restrictions is different. And hence, the explanations behind the disputes are different than it was a decade ago.

Now, the main reason for the most trade disputes involving Asia is new users. New users now account for about 60 percent of all cases against Asia-Pacific nations. Furthermore, more than half of these cases are initiated by other Asia-Pacific nations. In other words, many of the trade disputes are intraregional disputes.

Rather than viewing this as a problem, the intraregional nature of many

14. One piece of information that would be useful to know is how much trade has been affected by the increased number of AD investigations. Because the WTO reports provide almost no information on the products covered, that task will have to be delayed until a later date. 


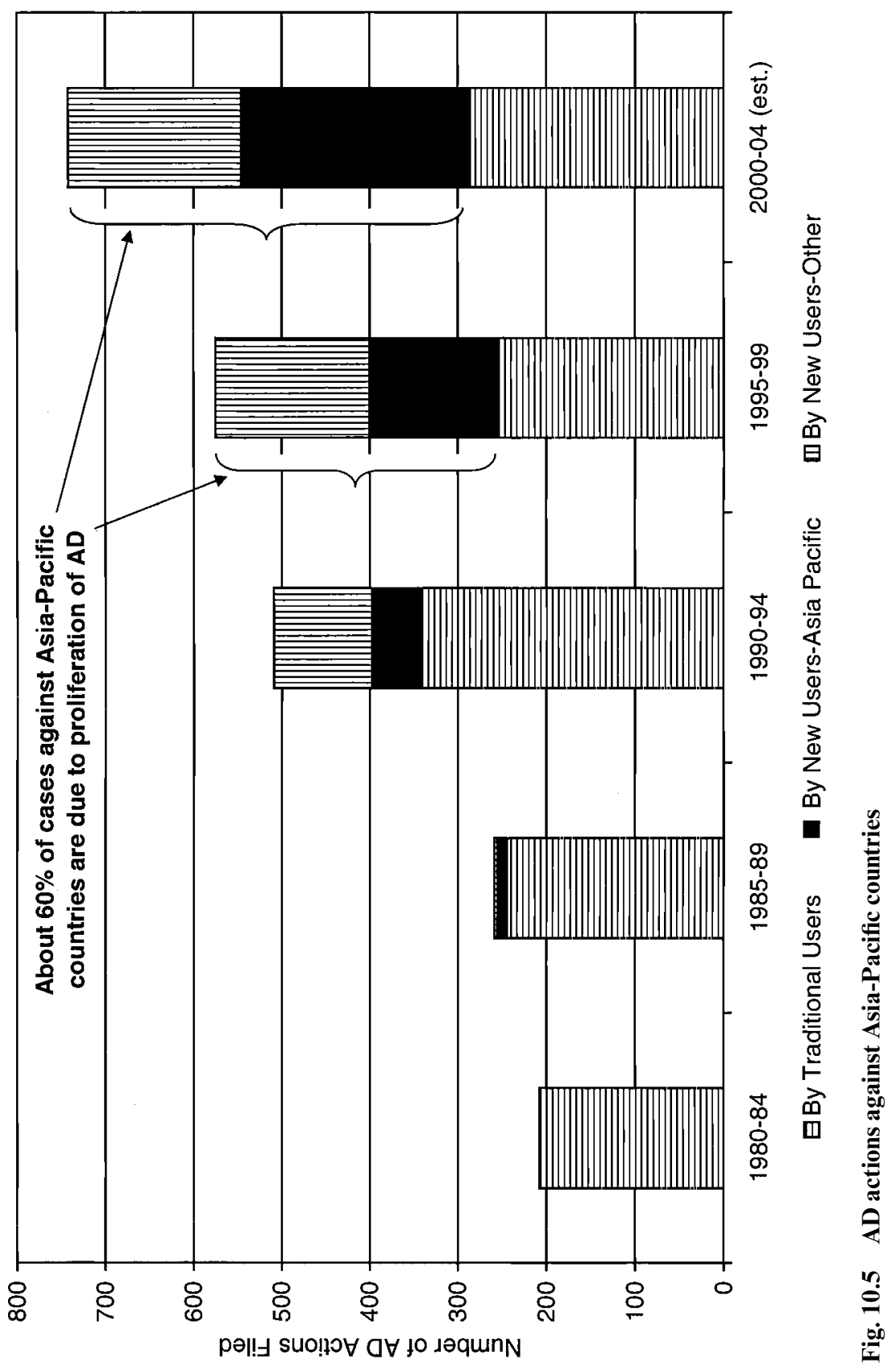


of the disputes points to a potential solution to the AD problem. Namely, regional trade agreements might be the light at the end of the tunnel. Even under the most optimistic scenarios, significant AD reform within the WTO is unlikely. The entrenched positions of the United States and EU make such a scenario unlikely. On the other hand, we now have several examples of regional agreements that limit, or prohibit, AD use within the free trade area. The earliest example is the European Community/European Union who prohibits AD actions within the union. The TransTasman pact prohibits antidumping disputes between Australia and New Zealand. The recent Chile-Canada Free Trade Agreement also prohibits antidumping disputes.

If Asia-Pacific nations want to curb antidumping it is likely that the only real prospect is via regional agreements. Once enough such agreements are signed, the WTO negotiations have much greater likelihood of succeeding.

\section{References}

Areeda, Phillip E., and David F. Turner. 1975. Predatory pricing and related practices under section 2 of the Sherman Act. Harvard Law Review 88:697-733.

Blonigen, Bruce A., and Thomas J. Prusa. 2003. Antidumping. In Handbook of international trade, ed. E. K. Choi and J. Harrigan, 456-76. Oxford, UK: Blackwell Publishers.

Clarida, Richard H. 1996. Dumping in theory, in policy, and in practice. In Fair trade and harmonization, ed. J. Bhagwati and R. Hudec. Cambridge: MIT Press.

Cohen, Stephen D., Robert A. Blecker, and Peter D. Whitney. 2003. Fundamentals of U.S. foreign trade policy. 2nd ed. Boulder, CO: Westview Press.

Durling, James P. 2003. Deference, but only when due: WTO review of antidumping measures. Journal of International Economic Law 6 (1): 125-53.

Feinberg, Robert M. 1989. Exchange rates and unfair trade. Review of Economics and Statistics 71 (4): 704-07.

Finger, J. Michael, Francis Ng, and Sonam Wangchuk. 2001. Antidumping as safeguard policy. World Bank Working Paper no. 2730. Washington, DC: World Bank, December.

Gallaway, Michael P., Bruce A. Blonigen, and Joseph E. Flynn. 1999. Welfare costs of US antidumping and countervailing duty laws. Journal of International Economics 49:211-44.

Horlick, Gary N. 1989. The United States antidumping system. In Antidumping law and practice, ed. J. H. Jackson and E. A. Vermulst, 99-166. Ann Arbor: University of Michigan Press.

Knetter, Michael M., and Thomas J. Prusa. 2003. Macroeconomic factors and antidumping filings: Evidence from four countries. Journal of International Economics 61:1-17.

Lindsey, Brink. 1999. The US antidumping law: Rhetoric versus reality. CATO Institute Center for Trade Policy Studies Working Paper no. 7. Washington, DC: CATO.

Lindsey, Brink, and Dan Ikenson. 2002. Antidumping 101: The devilish details of 
'unfair trade' law. CATO Institute Center for Trade Policy Studies Working Paper no. 20. Washington, DC: CATO.

Mastel, Greg. 1998. Antidumping laws and the U.S. economy. Armonk, NY: M. E. Sharpe.

Messerlin, Patrick A. 1989. The EC antidumping regulations: A first economic appraisal 1980-85. Weltwirtschaftliches Archiv 125:563-87.

2001. Measuring the costs of protection in Europe. Washington, DC: Institute for International Economics.

Miranda, Jorge, Raul A. Torres, and Mario Ruiz. 1998. The international use of antidumping: 1987-1997. Journal of World Trade 32:5-71.

Prusa, Thomas J. 2001. On the spread and impact of antidumping. Canadian Journal of Economics 34 (3): 591-611.

Prusa, Thomas J., and Susan Skeath. 2004. Modern commercial policy: Managed trade or retaliation? In Handbook of international trade, Vol. 2, Economic and legal analysis of trade policy and institutions. ed. E. K. Choi and J. Hartigan. Cambridge, MA: Blackwell.

Staiger, Robert W., and Frank A. Wolak. 1994. Measuring industry specific protection: Antidumping in the United States. Brookings Papers on Economic Activity, Microeconomics: 51-118.

Stiglitz, Joseph E. 1997. Dumping on free trade: The US import trade laws. Southern Economic Journal 64:402-24.

Viscusi, W. Kip, John Vernon, and Joseph E. Harrington, Jr. 1995. Economics of regulation and antitrust. 2nd ed. Cambridge, MA: MIT Press.

Zanardi, Maurizio. 2004. Antidumping: What are the numbers to discuss at Doha? The World Economy 27 (3): 403-33.

\section{Comment Takatoshi Ito}

Dr. Prusa's paper shows the pattern and characteristics of antidumping (AD) filings since 1980. The paper is a great source for statistics on AD users and countries targeted by AD. Among many interesting findings in the paper, the following stands out. The number of AD cases has increased dramatically, but so was trade. A concept of AD intensity, defined as the number of AD filings divided by real imports and normalized against the U.S. average (1980-2002), is introduced for further analysis. Initially, the United States, the European Union (EU), Canada, and Australia (the traditional users) have dominated in filing AD cases, both in the raw number and in intensity. However, in recent years, a new set of countries has been using AD more aggressively. An increase in the AD intensity recently is due to an increase of the new users rather than an increase in the use of the traditional users. Among the new users, India filed a large number of cases, and its intensity is high, followed by New Zealand, Argentina, Turkey,

Takatoshi Ito is a professor at the Research Center for Advanced Science and Technology, University of Tokyo, and a research associate of the National Bureau of Economic Research. 
Poland, South Africa, India, and Indonesia. As for the target countries, the East and Southeast Asian countries have been heavily targeted. Proliferation of $\mathrm{AD}$ in recent years is more due to new users than the traditional four. In terms of targets of the AD actions, two features are prominent. First, American countries and countries in the EU have been hitting each other with AD actions. Second, Asian countries have been targeted more than countries in any other region. In analysis of what explains AD actions, it is found that, among other obvious factors, the real exchange rate is particularly important in the determination of $\mathrm{AD}$ filing by traditional users.

My comments are centered on questions about whether the findings are surprising and whether any other interesting facts can be found from his rich statistics. Before answering these questions, I have to review the basics of the concept of dumping.

Dumping is an act to sell goods at an "unfairly" low price (that is, below normal value) for exports. Producers in a country where the exports were "dumped" have to prove that they suffer an "injury" resulting from dumping. However, the concept of dumping has been a source of controversy because "unfairly low prices" (or normal value) and "injury" are difficult to define in economic terms.

Dr. Prusa correctly points out AD has been a thinly veiled device for protectionism, because it is difficult to find a genuine case of "dumping" from the theoretical point of view. The definition of AD used in the real world is far from one that could be justifiable in economic theory. I fully agree with this argument. The AD can be applied in practice when the three conditions are met: (a) when the imported price (PM) to country $U$ from exporting country $K$ is "unfairly" low (below normal value), (b) when imports cause an "injury" to domestic industry of country $U$; and (c) when there is a causal link from (a) to (b).

The first condition is troublesome because mainstream economic theory typically does not offer a concept of "fair" price or normal value. How about the average price (AC) of the firm of country $K$ ? If the company is selling goods in country $U$ at below-average price (that is, losing money), then the company is charged to be "dumping." But is selling goods at prices below AC necessarily an "unfair" act? Probably not. If the fixed cost, say assembly lines at home and a distribution network in country $U$, is already sunk, then companies have incentives to produce and sell at or above marginal costs (MC), and most economists think that $\mathrm{PM}>\mathrm{MC}$ act to be "fair." Then how about a case where exporters are selling at lower prices than MC? Is a condition PM $<\mathrm{MC}$ unfair? However, MC is harder to calculate, especially when a product in question is one of the many products produced by the company. The third possible way, and in fact most common in practice, to define a fair price is to compare PM to do- 
mestic price of the same goods in the exporting country, $K .{ }^{1}$ It is difficult to establish whether the domestic price is "normal" to begin with. Moreover, what if products sold domestically in country $K$ are slightly different in specifications and durability from products sold in the export market in $U$ ?

If the exporting firm has a monopolistic power to discriminate the two markets in $K$ and $U$, then prices they charge may be quite different as a natural result of profit maximization, depending on the price elasticities of demands in the two markets. It is quite possible that profit maximization with discriminating prices would make the prices in $U$ lower than prices in $K$, with different design of products. But is it unfair? Probably not. So, there is little basis to prove the first condition of $\mathrm{AD}$ from the purely economic point of view. The definition is inherently political.

The difficulty also exists in the definition of "injury," the second condition for dumping. What is injury? Economic theory may arguably define injury as a situation where the sum of consumers' surpluses and producers' surpluses are reduced by a deliberate act of trading partners (companies or the government). If consumers' surpluses increase more than producers' profits due to cheaper imports being introduced, the nation's welfare most likely increases. ${ }^{2}$ However, in practice, the injury is often measured by sales and profits of producers that compete against imports. First of all, the country would not be able to use AD if there is no import-competing firm. Most of the least-developed countries and small economies with limited range of products would not be able to use AD. Suppose that there are companies that produce goods that compete against imports. When the market share of domestic firms goes down sharply, while the market share of imports goes up sharply, then injury is easier to prove. Even if imports are increasing the market share, the expanding market may absorb the increase without decreasing the domestic firms' sales. In that case, injury is less likely to be proven legally. When the market is not expanding and an increase in imports is roughly matched by a decline in domestic production, the case for injury more likely holds up. Therefore, dumping is less likely to be brought up in the growing stage of the industry or product cycle

1. According to the WTO rule, "[T]he normal value is generally the price of the product at issue, I the ordinary course of trade, when destined for consumption in the exporting country market" (http://www.wto.org/english/thewto_e/whatis_e/eol/e/wto04/wto4_7.htm).

2. A proponent of the use of AD may argue that even if the gains by consumers may exceed the producers' losses in the short run, the foreign companies may increase the prices once the domestic firms become extinct. This is called predatory behavior, most likely a violation of antitrust (antimonopoly) law. This is a theoretical possibility, and many economists would agree that such a behavior should not be tolerated. However, it is very difficult to prove this has happened because often it is very difficult to hold on to monopoly power, unless it is based on patented technology or a brand name. Even patents become obsolete in competition for better technology and a brand name can be challenged in the long run. 
but more likely in the mature market or declining stage of products in the importing country.

Let me next answer the question of whether findings in this paper are surprising. Based upon the practical interpretations of "unfair prices" and "injury" explained previously, what are the most likely countries that would bring up the case of AD. We expect that AD is used by large Organization for Economic Cooperation and Development (OECD) countries in the industries or products that have become rather stagnant. The traditional users identified by the author fit this description. Therefore, for that part, it is not surprising.

A surprise comes in the analysis of AD intensity, the number of AD filings adjusted for their real exports. Even a small country can be an intensive user of $\mathrm{AD}$ in these statistics. However, we would expect that $\mathrm{AD}$ users are more or less advanced in some industries so that they are threatened by imports to those industries from other less-developed countries. Some of the users, like New Zealand and Argentina, fit the description. However, other countries such as India, Egypt, South Africa, and Indonesia are less obvious from prior observations.

In the list of AD heavy users, measured either in number or in intensity, wealthier Asian countries-Japan, South Korea, and Taiwan - are conspicuously absent. This is more surprising than natural. These countries have high-income countries and have a wide range of industries, some of them are more or less matured. Let us explore reasons for the lack of AD use by wealthier East Asian countries. Exporters of these countries have traditionally been late comers compared to western firms and have been expanding their shares in other countries, not to mention in the domestic markets. The domestic economies were expanding rapidly in the highspeed growth, and these countries were in the position to chase the frontrunner of the United States and EU in many industries from the 1980s to 1990s. From textiles to electronics, to steel, and to automobiles, East Asian firms have grown from domestic-only firms to global players. There was no need to complain about imports from abroad at the domestic market. This explanation may be sufficient for the 1960s and 1970s. But Japan has seen increases in imports of manufactured goods from other Asian countries since the early 1990s. Imports of color televisions have surpassed the domestic production in the late 1990s. However, AD has rarely been used by Japan. ${ }^{3}$ I only list some of possible explanations of why Japan has been so restrained: first, the Japanese government, with power over industries, may be a model student of the General Agreement on Tariffs and Trade/World Trade Organization (GATT/WTO; maybe except for agricultural prod-

3. The most prominent case of protection from imports was Japan's attempt of using safeguard against three agricultural products from China in 2001. After China announced the use of retaliatory tariffs, the two countries settled the disputes without making them into a trade war. 
ucts) not to use unjustifiable trade restrictions; second, Japan may have been afraid of retaliation by countries that absorb its exports, that is, Japan may lose more than gain when AD actions lead to a trade war; third, Japan may lack an institutional framework, such as U.S. trade representatives (USTR) and the ability of shrewd legal maneuvering to impose AD while avoiding being hit by retaliatory actions.

The fact that Asian countries have growth rapidly with increasing manufacturing exports made them vulnerable to AD actions against them. It has been shown in figure 10.5 that AD actions against Asia-Pacific countries were taken mostly by the traditional users of AD until 1994. After 1995, about 60 percent of cases against Asia-Pacific countries were taken by new users of $\mathrm{AD}$. One of the reasons why $\mathrm{AD}$ actions by traditional users have declined may be that Japan and Korea have been invested directly in countries that have had trade disputes. For example, Japanese consumer electronics and automobile investments in North America have lessened trade conflicts between the two countries, although automobiles have not been products for $\mathrm{AD}$ actions. AD actions by new users against Asian countries are an interesting phenomenon. This suggests that lessdeveloped countries have become users against imports from moredeveloped countries. For example, China took AD actions against Japan in seven products from 2000 to 2001. Indeed, this is a new pattern.

In summary, this is a very interesting paper analyzing $\mathrm{AD}$ actions with a large data set. Some results are expected by common sense observations based on political economy, while some other results are new. The observed patterns and regression results are rich enough that they may stimulate more work in this area.

\section{Comment Chong-Hyun Nam}

This is an interesting and highly informative paper. Thomas Prusa carefully reviews the General Agreement on Tariffs and Trade/World Trade Organization (GATT/WTO) rules related to antidumping (AD), explaining how easily they can be abused for protectionist purposes. Prusa then investigates the trends and historical development of $\mathrm{AD}$ actions with utmost care and with special attention being given to Asia-Pacific countries.

Let me first say that I have little disagreement with what Prusa said in the paper. A good analytical work, however, often raises more questions than it answers. My comments are therefore largely devoted to raising questions with some considerations that the author may want to consider for further work or, perhaps, in other papers. 
My first question is concerned with the astonishingly rapid increase and widespread AD actions across countries, particularly for the past dozen years or so. More alarming is that the intensity of $\mathrm{AD}$ actions undertaken by the new users is incredibly high, as much as five, ten, even twenty times that of the United States. Why did it happen? How can one explain this? Prusa puts forth a good argument for that. That is, the new users tend to be mostly developing countries, including such countries as Argentina, Mexico, South Africa, and India, and they have long suffered from AD actions by the traditional users. The traditional users happen to be mostly advanced countries, including such countries as the United States, EU, Canada, and Australia. Prusa suggests that the new users have finally learned the important lesson from the traditional users that AD is not only profitable but also is a WTO-consistent way of restricting foreign imports.

I agree with Prusa's argument, but I may add a few more arguments to that. One is the possibility of the so-called predatory AD argument. I wonder if there is some truth in it, though I have no hard evidence for that. I recall that, when I served as a member of the tariff board for the Korean government some years ago, I heard this argument most frequently from Korean AD petitioners. This argument may not make much sense when it is used by advanced countries against imports from developing countries because imports from developing countries tend to be more or less highly competitive and more-standardized products.

This argument, however, may gain some steam if it is used by the new AD users against imports from advanced countries because imports from advanced countries are likely to include more high-tech oriented commodities for which they have some price discriminating power in international markets. It may be worth it, therefore, to explore this point further.

Another argument is that policy options available for developing countries to protect their domestic firms or industries have become rather thin in recent years. In the past, developing countries enjoyed flexibility in their use of trade and industrial policies under the GATT's rules of the so-called special and differential treatment. Through successive GATT/WTO rounds, however, their tariff and nontariff barriers have been substantially reduced or entirely eliminated, and at the same time, their industrial subsidy programs have gone through a rationalization process because they have been heavily countervailed by advanced countries. So many developing countries may have been driven to rely more on the modern (?) form of protection like $\mathrm{AD}$ actions than before, as was the case for advanced countries in the past.

My second question is why then has AD emerged as the most popular means of protection, much preferred to other means of protection, such as safeguard or countervailing duties (CVD)? This point is shown very well in figure 10.1 in the paper. Needless to say, this is because the threshold for the use of $\mathrm{AD}$ is much lower and less costly than the use of safeguard or 
CVD. For instance, AD is basically dealing with individual firms for their private subsidies, whereas CVD is dealing with foreign governments for their public subsidies. On the other hand, the use of safeguard measures risks retaliation if adequate compensation is not being made to its trading partners. All of these would have helped to make AD a more preferred form of protection to the safeguard or CVD measures.

A natural question to ask is what we can do about the abuse of AD actions for protectionist purposes. An easy answer to this question is to make it harder to use the AD measure. Prusa seems to have a rather dim view on this possibility because neither the traditional AD users nor the new users would be interested in changing the current $\mathrm{AD}$ rules at the moment. That may be true. But the abuse of AD rules somehow needs to be brought under control, and that can be done only by the WTO, I suppose. Perhaps Asia-Pacific countries may play a major role in that direction. They may begin with easy things to agree upon to change the AD rules. For instance, they may try to have AD petitioners pay a penalty or bear part of lawyer expenses for any invalid charges they make. At the same time, the WTO needs to make more efforts to amend the current safeguard rules by relaxing the requirement for compensation so that it can become a main route for temporary import relief. Import restrictions would be, at least, more transparent and nondiscriminatory under this route.

There is one final comment. I would have liked it very much if the paper could have provided even a crude estimate about trade impacts of AD actions undertaken by the traditional users, or by the new users, or by both. That will help a great deal for us to understand the nature and economic costs involved with $\mathrm{AD}$ actions. 
